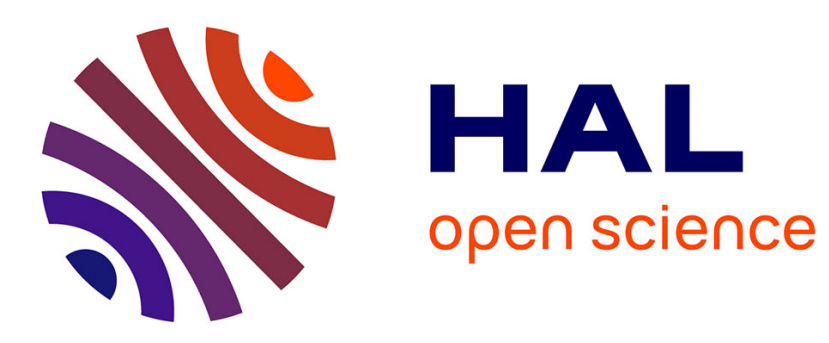

\title{
Human Rights as Transnational Constitutional Law
}

\author{
Samantha Besson
}

\section{To cite this version:}

Samantha Besson. Human Rights as Transnational Constitutional Law. Anthony F. Lang; Antje Wiener. Handbook on Global Constitutionalism, Edward Elgar, pp.234-247, 2017, Research Handbooks on Globalisation and the Law Series, 978178347725 8. 10.4337/9781783477357.00027 . hal02516341

\section{HAL Id: hal-02516341 \\ https://hal.science/hal-02516341}

Submitted on 11 May 2020

HAL is a multi-disciplinary open access archive for the deposit and dissemination of scientific research documents, whether they are published or not. The documents may come from teaching and research institutions in France or abroad, or from public or private research centers.
L'archive ouverte pluridisciplinaire HAL, est destinée au dépôt et à la diffusion de documents scientifiques de niveau recherche, publiés ou non, émanant des établissements d'enseignement et de recherche français ou étrangers, des laboratoires publics ou privés. 


\section{Human rights as transnational constitutional law* Samantha Besson}

\section{INTRODUCTION}

Human rights are often taken to epitomize the existence of global constitutional law ${ }^{1}$ or, at least, of global constitutionalism (see Klabbers et al. 2009; Wiener et al. 2012). Since 1945, human rights have been protected through both domestic (constitutional) human rights law (DHRL) and international ${ }^{2}$ (universal and/or regional ${ }^{3}$ ) human rights law (IHRL), and monitored and interpreted by their corresponding domestic and international human rights institutions ${ }^{4}$

This has led to well-known and extensive discussions about the dual (see Neuman 2003; Waldron 2011; Besson 2015a, 2017a) constitutionalization (or positivization) of human rights and/or about the duality of constitutional law itself (see Kumm 2009, 2012 Besson 2009a, 2014; Krisch 2010). Previous discussions have explored this constitutional duality by looking at how international human rights law may be regarded as a (formal or material) constitutional regime within international law (see Gardbaum 2008; Besson 2009a), on the one hand, and at how it may endorse a constitutional function domestically and/or internationally (see Gardbaum 2008; Besson 2015a), on the other. This chapter takes the debate one step further and complements these dual approaches to human right law with a more integrated conception or, in short, with a truly transnational or global

* Many thanks to Tony Lang and Antje Wiener for their invitation to contribute; to Folke Tersman, Patricia Mindus and the participants in the Higher Philosophy Seminar at the University of Uppsala on 26 February 2016 for their comments; to José Luis Martí and Andreas Føllesda and the participants in the Barcelona workshop on 6-7 May 2016 for their feedback; and to Allen Buchanan for our many exchanges on human rights epistemology. I would also like to thank Gaelle Mieli for her research and editorial assistance.

'Constitution' or 'constitutional law' is used here in a thick sense to refer to a set of legal norins of higher rank (entrenched; in a formal sense) and whose content is fundamental or constitutive (in a material sense). 'Constitutionalism' amounts to any kind of theory pertaining to the existence or content of constitutional law. See also Besson (2009a).

This chapter focuses on the European Convention on Human Rights (ECHR) and the European Court of Human Rights'(ECtHR's) case-law. Some of the argument may then be generalized to other regimes in IHRL, as I will explain.

Both 'regional' and 'universal' regimes of international human rights law are embraced under the umbrella notion of 'international human rights law'. Their relations are those between regimes of international law (see Brems 2014, Besson 2017b).

Unless specified otherwise in the course of the argument, domestic and international human rights 'institutions' include courts as much as other legislative or administrative bodies.

Of course, the term 'global' could also be used to refer to the universal scope of IHRL by contrast to their regional scope. In this chapter, however, it will be used interchangeably with 'transnational', to encompass all the law-making processes or sources of human rights law whethe domestic or international and, in the latter case, whether regional or universal. one. It proposes to explore the extent to which the domestic and international human rights law regimes are complementary and hence best approached together as 'transnational human rights law' (see McCrudden 2000, p. 530; Hessler 2005, p. 37; Waldron 2005 , p. 423, 2011, 2012; Besson 2015a, 2017a) or, as it is sometimes also referred to, as 'transnational constitutional law' (see McCrudden 2000, p. 530).

While scholars have mapped transnational aspects of the human rights practice, and especially transnational comparisons in domestic (constitutional) and international human rights law (see, for example, McCrudden 2000, 2007, 2013, 2015, 2017; Halmai 2012; Hirschl 2014; Jackson and Tushnet 2014), this is not yet true of their theoretical or philosophical underpinnings. Curiously, the exact nature, justifications, determination and implications of the 'transnationality' of human rights law remain largely undertheorized (see McCrudden 2000, pp. 522, 532; see, however, Waldron 2005, 2011, 2012; Besson 2015a; McCrudden 2017).

This chapter aims to remedy this theoretical gap. Starting from what it describes as the transnational practice of human rights law and developing the best interpretation thereof, the chapter discusses what transnational human rights law both does and should amount to, and especially from where it could draw its legitimate authority. The chapter's argument is three-pronged, accordingly. The next section differentiates the notion of transnational human rights law from other conceptions of transnationality used in legal scholarship. In the third section, the chapter develops a transnational interpretation of the domestic and international regimes of human rights law that both fits and justifies their dual and complementary practice. The fourth section accounts for some of the central methods for determining transnational human rights law, and in particular human rights comparison and the transnational consensus it identifies. The chapter concludes with a discussion of some implications for the future practice of domestic and international human rights law.

\section{THE TRANSNATIONALITY OF HUMAN RIGHTS LAW} DEFINED

The 'transnationality' of human rights law captures what is specific about its sources or law-making processes, both domestic and international, and about each of them taken individually or together with the others (see also Besson 2015a, 2017a). More specifically, the transnational nature of human rights law corresponds, as I argue in the next section, to the dual and complementary processes or sources through which domestic and international human rights laws are made, interpreted and enforced, and hence mutually validated and legitimated.

In connection with law generally, first, transnationality has been used to refer to and qualify, alternatively or in combination (see, for example, Scott 2009; Shaffer 2016), a variety of legal dimensions. It has been used by reference to, for instance: a legal order/a set of legal norms or standards distinct from domestic and international law (see, for example, Scott 2009, pp. 873-4) or, on the contrary, combining both (see, for example, Halliday and Shaffer 2015; Shaffer 2016); private legal subjects and/or lawmakers that are distinct from those of public domestic and international law (see, for example, Muir Watt 2011; Michaels 2014); a legal context including cross-border issues or problems involving 
more than one state or jurisdiction (see, for example, Jessup 1956, pp. 2-3, 136); a complex type of normativity beyond legality that mixes social, religious, moral and legal norms; or, finally, a pluri-disciplinary (often, socio-legal) and/or critical method in legal theory (see, for example, Teubner 1996; Twining 2009; Scott 2009; Zumbansen 2013, 2015) or even in legal education (see, for example, Arjona et al. 2015; Zumbansen 2015).

Human rights, secondly, are often mentioned as a paradigm example in discussions of transnational law. Their transnational dimensions may match some of the previous dimensions of transnational law, albeit not necessarily all of them. The qualification 'transnational' has been used to refer to and qualify, alternatively or in combination (see, for example, Vandenhole 2012; Gibney and Vandenhole 2014), specific dimensions of the human rights practice, and for instance the following: the identity of human rights duty-bearers beyond the state, and especially private (individual or collective) actors (see, for example, Vandenhole 2012; Pavlakos 2015) and/or international institutions (see, for example, Besson 2015b; Vandenhole 2015); the making of human rights standards, whether they are private law (see, for example, Vandenhole 2012) or even soft law standards (see, for example, Engle Merry 2015); domestic fora of human rights litigation outside of or including the state of jurisdiction (see, for example, Zumbansen 2005), of judicial dialogue on human rights (see, for example, Zoethout 2015) or of cross-border human rights advocacy by non-state actors (see, for example, Keck and Sikkink 1998); the scope of states' human rights duties beyond their respective (territorial or extra-territorial) jurisdiction (see, for example, Gibney et al. 1999; Skogly and Gibney 2002; Besson 2015b, 2017c; Pavlakos 2015; Vandenhole 2015), and what becomes their application's condition or trigger if it is no longer a matter of jurisdiction; the method of determination and interpretation of human rights' duties, whether it is by analogy, comparison, borrowing (see, for example, Klug 2005); or, finally, a method of enquiry or field of socio-legal research (see, for example, Klug 2005).

None of these conceptions of the transnationality of human rights law captures this chapter's understanding of human rights law as an integrated or common regime of law. Importantly, moreover, the transnationality of human rights law, as it is understood in this chapter, should not be conflated with legal plurality (often also referred to as 'legal pluralism'; Besson 2009b; 2012a; 2015c) in human rights law, whether in the socio-legal sense of the concept or the strictly legal one.

Starting with the former, first, that is to say legal plurality in the socio-legal or anthropological sense (see Engle Merry 1988; Zumbansen 2010), the proposed argument is compatible with the plurality of sources of norms at play in a given legal situation, some stemming from official or public law and others less so. However, this is not what the transnationality of human rights law discussed here is about. The proposed argument focuses instead on human rights as public or official legal rights and duties, and not on other types of norms applicable in the legal context such as religious norms or private norms in particular. Its object is the human rights' duties established by and for states (see Besson 2013b; 2015b) and hence those that are generated through the states' domestic and international public law.

With respect to the latter, secondly, it is important to emphasize that the relationship propounded between domestic and international human rights law is one of complementarity, and not of competition. The pluralistic qualification should be retained for the relations between competing international legal norms and regimes, including within international human rights law itself (for instance, between regional and universal international human rights law or within any of them), that protect the same object in different ways and between which normative conflicts may arise. It is not the way domestic and international human rights law relate in practice, however, and not the way I argue they should either (contra: Krisch 2010; Kunm 2012). Both sets of legal norms protect the same rights, and there can be clashes between domestic and international institutions' interpretations of these same rights. However, these interpretations do not compete, as we shall see, but apply only in a sequence and in order to complement one another. This relationship of complementarity (or subsidiarity stricto sensu; Besson 2016b) cannot be qualified as pluralistic, as a result (see Hessler 2005; Besson 2014; 2015a).

\section{THE TRANSNATIONALITY OF HUMAN RIGHTS LAW JUSTIFIED}

What the complementarity or transnationality of human rights law captures is how both the domestic and the international legal norms protecting human rights relate in a way that is uncommon in international law (Besson 2015a; see also McCrudden 2015, pp. 536-8): they are not only situated in a relationship of top-down transposition and/or enforcement of an international standard in domestic law, but also in a relationship of bottom-up international recognition and consolidation of the transnational or common law stemming from different domestic legal orders into an international standard. More specifically, that relationship is mutual, on the one hand, to the extent that the domestic and international human rights law-making and law-ascertaining processes are comparative and hence transnational at both the domestic and the international levels. It is also dynamic, on the other hand, to the extent that it does not only start domestically and end internationally, but there is constant normative toing and froing between the two levels of legal protection.

The minimal content of international human rights law evolves together with that of their transnational domestic practice as a result. This usually implies a levelling-up of the international minimal human rights standard, but we cannot preclude some degree of levelling down. The latter is made harder by the international entrenchment of the transnational minimal human rights standard; because that standard requires the same level of transnational commonality to evolve one way or the other, levelling down is rare in practice (on moral progress and human rights, see, for example, Buchanan 2013).

We may wonder about the justification for this transnational legality of human rights in practice. Prima facie, indeed, international law has the kind of universal material scope that matches that of universal moral rights. It would seem therefore to provide the privileged order for the legal protection of human rights knowing that international human rights law claims to bind all states and hence to be universally justified. This applies whether legal human rights are merely considered to recognize existing universal moral rights, or (also) to contribute to these rights' specification or even to their creation (on moral and legal human rights, see Besson 2012b, 2013a).

The primary justification for the transnational legality of human rights lies in the egalitarian and accordingly democratic dimension of human rights. As I have argued elsewhere, human rights are constitutive of our equal basic moral status (see Buchanan 
2010b; Besson 2012b). It follows that human rights' holders and duty-bearers should participate in the process of recognizing and specifying their equal and mutual rights. Accordingly, the process through which their recognition and specification take place ought to be egalitarian and public, and include all those whose rights are affected and whose equality is at stake. What this means is that human rights should be recognized and specified as equal rights through a procedure that guarantees their public equality, that is, a democratic procedure. As a result, given international law's inherent democratic limitations, but also because international human rights' duties bind states to people under their jurisdiction and not some international community of states and/or individuals (see Besson 2015b), using international law as the sole order where we should recognize fundamental and general human interests as sufficiently important to generate duties of states at the domestic level would not be sufficiently egalitarian and democratically legitimate (see Cohen 2008, pp. 599-600; Besson 2013c).

At the same time, of course, certain minimal egalitarian conditions have to be met for the domestic recognition and specification of human rights to be democratic. These minimal conditions of public equality should be guaranteed externally and constrain the domestic polity. This is where international human rights law, and the minimal democratic guarantees it constitutes such as the right to political participation, freedom of expression and association and non-discrimination rights, come into the picture. However, for these minimal democratic and human rights constraints in international law to be democratically legitimate in the first place, they should draw from the transnational common ground shared in the practice of states that regard each other as democratic. Importantly, they need not have (yet) been protected as rights to be recognized as international human rights, but only substantially realized so as to constitute a minimal common ground among democratic states.

International human rights law's democratic legitimacy requires, therefore, that it originates from the transnational consolidation of the domestic human rights law and practice of democratic states, albeit constraining these states minimally in return at the same time (see Besson 2011, 2013c, 2015a). Later on, only the domestic human rights practices regarded as minimally democratic according to the common standards entrenched in international human rights law may and should be considered in the further transnational development of these minimal international human rights standards and as potential candidates for entrenchment into a new international minimal human rights standard (see Hessler 2005, p. 48 ff.).

This democratic argument for the legitimacy of the transnationality of human rights law, and the mutual validation of domestic and international human rights law, corresponds to what I have referred to elsewhere as the mutual democratic legitimation of domestic and international human rights law (see Besson 2011, 2013c, 2015a; see also Buchanan 2004, pp. 187-9, 2011; Buchanan and Powell 2008, pp. 348-9). The interaction between (international) human rights and (domestic) citizens' rights is also reminiscent of Hannah Arendt's universal right to have particular rights and the complementarity between the universal and the particular. Human rights are first specified as citizens' rights, but citizens' rights progressively consolidate into human rights which constrain them in return while also developing further through them (see Arendt 1951; Benhabib 2011, pp. 16, 126; Habermas 2011, pp. 31-2, 36-8).

Besides the democratic justification for the transnational legalization of human rights, I should also mention a second justification: an epistemic justification. Given the concrete nature of human rights duties, their existence and content is best identified in domestic circumstances. Human rights being equal rights, this is indeed the socio-comparative context in which the general threats to the interest protected by a given human right can be assessed and the potential corresponding duties identified (see Besson 2012b, 2013b).

Again, however, this specification requires some minimal epistemic conditions to be respected. These conditions are best imposed from the outside through international human rights law (for example, freedom of assembly, freedom of speech, religious freedom and non-discrimination rights). However, this should be done in a way that starts from the epistemic conditions experimented and tried out previously in domestic circumstances in the context of the recognition of human rights and the determination of the corresponding duties. As before, once these minimal epistemic conditions are entrenched internationally, only the practice of the states embodying them shall be considered for the further interpretation and development of international human rights law and with a view to considering their new common interpretations as part of the international standard.

This approach to human rights epistemology, like Allen Buchanan's, relies on a moral epistemology that is 'social' (see Buchanan 2010a, 2017), and even socio-political given how human rights are constitutive of our public status as equals. Because our social context may also distort our beliefs about our rights, the epistemic conditions experimented and tried out previously in domestic circumstances where human rights have developed should be those where these rights are already substantively realized. This is what Buchanan has described as the 'reflexive' dimension of the moral epistemology of human rights (see Buchanan 2017).

These minimal epistemic conditions for the determination of human rights come close, in their role and content, to the minimal democratic conditions referred to earlier. It is actually common in practice to see a combination of the democratic and the epistemic justifications for the complementarity of domestic and international human rights law. From a democratic theory perspective, the combination is not surprising since epistemic justifications are often put forward for democratic procedures themselves (see, for example, Martí 2006). What this means for the epistemology of human rights, is that the minimal epistemic conditions actually amount to some minimal form of substantive realization of democracy.

A ready objection to the epistemic argument for transnational human rights law, and arguably also to the democratic one, is the universality of human rights ("universalityobjection'). Someone could indeed consider that the transnational consolidation of domestic specifications of human rights may lead to recognizing parochial conceptions of human rights as minimal international human rights standards, thereby contradicting their claim to a universal justification (see, for example, Brems 1996; Benvenisti 1999).

The best way to reply to the universality objection is by bringing in the more widespread and exact reverse objection: the 'parochialism objection' to the universality of international human rights law itself. The latter objection is usually opposed to the claimed universality of international human rights law and based on what it regards as the largely parochial or cultural conceptions stemming from one dominant culture or set of cultures and imposed by international human rights law in the name of universality on others. The objection has different grounds: international human rights law may be parochial because there is no universal moral standard to start with or, in a more pluralist version 
of the objection, because there is more than one universal moral standard, on the one hand, or, in a less sceptical version of the objection, because of our epistemic limitations, on the other (for the other parochialism-objections to the universality of human rights, see Buchanan 2008, 2017; Besson 2013a). It is the latter form of the objection that is antithetical to the universality objection opposed to the proposed account of transnational human rights law and the one I focus on now.

In reply to the universality objection, we may argue that the transnational making of human rights law actually amounts to a way to prevent parochial conceptions from being too quickly entrenched into international human rights law, and hence to protect the claimed universality of human rights from parochialism. As I argue in the next section, starting from many distinct domestic human rights' interpretations and comparing them on a transnational scale in order to identify a common ground, contribute to questioning the future international human rights standard and hence to making it less parochial. It prevents one domestic conception in particular from becoming too quickly, and without transnational probing, the international conception, and hence the alleged universal conception. In short, transnational human rights law could be seen as exhibiting a form of 'good parochialism' that should not be too quickly discarded if we are to protect the universality of human rights from the epistemic objection of 'bad parochialism'.

Importantly, this epistemic argument for transnational human rights law does not mean that human rights should be regarded as 'self-certifying' (see Buchanan 2017). It is not because we regard a particular transnational practice as amounting to the realization of transnational human rights law that should be entrenched as a minimal international standard that that practice necessarily corresponds to the (however pluralistic) universal moral truth or, later on, that it captures one of its (however multi-faceted) correct moral interpretations. We may be entirely wrong about them and should be ready to correct them ourselves. However, it is likely that we will be able to ascertain what human rights are better in conditions where what we think, after having compared our respective reasoning on a transnational scale, to be human rights are realized, than doing so alone either on a merely domestic or on a purely international scale. This is not to say that there are no epistemic qualities in existing international human rights institutions, such as, for example, their inclusiveness, representativeness or deliberativeness (on these epistemic qualities, see Buchanan 2011, 2017), but only that these are actually best understood as complementary and transnational in their functioning rather than unilateral and top-down. That is, the epistemic qualities usually granted to international human rights law and institutions are exactly those captured by their transnationality.

\section{THE TRANSNATIONALITY OF HUMAN RIGHTS LAW DETERMINED}

The transnationality of human rights law so justified has direct implications for how we should understand its sources, both domestic and international, that is, the way human rights law is made and specified in practice (for a full argument, see Besson 2016a; 2017a).

One common methodological feature to sources of human rights law is that they al use transnational human rights comparison to determine the existence of a transnational human rights consensus.

\section{Transnational Human Rights Comparison}

Since 1945, human rights comparison has become the main and shared method of domestic (see Waldron 2011, p. 423) and international human rights' institutions alike (see McCrudden 2014, 2015). It enables them to identify commonalities in the transnational domestic practice of human rights and, accordingly, to consolidate them into minimal international human rights standards. Importantly, these domestic and international comparisons pertain to both domestic and international human rights law and not only to one of them, and this whether it is operated by an international human rights body or court or domestic ones.

What differentiates transnational human rights comparisons from more traditional nineteenth-century constitutional comparisons is not only their authors and their scope, but also their function. If there is human rights comparison in the contemporary dual human rights regime, it is because human rights law is transnational and shares a common ground, not merely because it is interesting, or even strategic, to compare domestic practices and borrow from some of them (Besson 2018).

Because human rights' comparison plays a distinct function in transnational human rights law, its justifications are also distinct from those usually put forward for comparative constitutional law in general, such as conceptual clarification in particular (see McCrudden 2000; Waldron 2005; Waldron 2011, pp. 411, 418, 420 ff.). ${ }^{6}$ This has implications, in turn, for the authority of comparative human rights law and the transnational common law identified. Its authority is not only theoretical, for instance when a comparison is informative or persuasive, as is the case in comparative constitutional law in general (see McCrudden 2000, p. 513), but truly practical and hence binding (Waldron 2012, pp. $62,76,93$; Besson 2018). This applies to international human rights' courts and institutions, but also arguably to domestic ones.

The first justification for the authority of human rights comparison is democratic. Ironically, however, one of the most serious critiques usually put forward against the legitimate authority of comparative human rights law is the democratic critique. It is generally argued indeed that using human rights' interpretations stemming from other domestic jurisdictions amounts to a clear violation of the democratic principle (see McCrudden 2000, p. 501 ff., 529 ff.; Waldron 2011, p. 412 ff.). It follows from this chapter's argument about the mutual validation and legitimation of domestic and international human rights law, on the contrary, that comparative constitutional law provides the best way to grasp what is common among democratic states' human rights practice and hence what democracy amounts to minimally (see Buchanan 2004, p. 189; Besson 2018).

Independent from or additionally to the democratic justification, another justification for the authority of human rights comparison is epistemic. It echoes the epistemic justification for the transnationality of human rights law discussed previously in the

To that extent, it may even be misleading to refer to it as 'comparative international human rights law' as yet another branch of comparative international law (McCrudden 2015). Comparison is indeed inherent to the implementation of international human rights law itself (see Besson 2017b). 
chapter. Based on the proposed reflexive social-moral epistemology of human rights (see Buchanan 2010a, 2017), we may consider that human rights comparison is the best way to determine what human rights are. Because our beliefs may be distorted by our parochial social practices, it is important that a comparison takes place between different domestic and international human rights law and institutions, and therefore has a transnational scope. Methodologically, human rights comparison is grounded in the universality of human rights, but takes into account the need for local socio-political contextualization in the specification and interpretation of their corresponding duties and content (Besson 2018). So doing, it enables the constant passage from the universal to the particular, and from the latter to the former.

\section{Transnational Human Rights Consensus}

Unlike that which may be the case in other comparative law contexts, the comparative outcome that should be identified through human rights comparison is known in advance: this is the human rights" 'common law', 'common ground' or 'consensus' across the various domestic interpretations of human rights compared (Besson 2018). The minimal common ground so identified may then, if it is validated by international human rights law and institutions, become entrenched as a minimal international human rights standard that can bind domestic authorities in return and be submitted to their further interpretation and practice.

The terms used to capture the common ground in transnational human rights law vary considerably. The most common term is international, global or transnational 'consensus'. It is the case of the 'European consensus' in the ECHR's system (see Wildhaber et al. 2013), but we also find references to 'regional consent' in the American Convention on Human Rights' (IACHR's) system (see Neuman 2008).

The 'European consensus', or 'converging approach', corresponds to a form of interpretative custom of the ECHR developed among state parties (see Ziemele 2012). It is based on European states' general practice (the latter need not be unanimous, and is mostly based on a ratio of six out of ten states, on average; see Wildhaber et al. 2013), on the one hand, and their opinio juris, on the other.

The two elements constitutive of the consensus are verified by reference to various legal materials: some domestic (for example, domestic legislation or judicial decisions) and some international (for example, other international human rights treaties or norms and their interpretations by their respective international organs); some soft and some hard; some internal to some or all the states parties to the ECHR and some external to that group of States (see ECtHR, Demir and Baykara v. Turkey, paras 85-6; ECtHR, Sitaropoulos and Giakoumopoulos v. Greece, para. 66; see also McCrudden 2013; Ziemele 2012; Wildhaber et al. 2013; Besson and Graf-Brugère 2014; Dzehtsiarou 2015). The latter comparative reference to international law external to European states parties, or, at least, to those at stake in a given case, and hence to international law that does not bind them, has been contested (see Letsas 2010). The court has since then confirmed its universalizing practice, however (see ECtHR, Case of the National Union of Rail, Maritime and Transport Workers v. the United Kingdom, paras 76,98). What matters, it has stressed, is that the relevant evidence 'denote[s] a continuous evolution in the norms and principles applied in international law or in the domestic law of the majority of member States of the
Council of Europe and show[s], in a precise area, that there is common ground in modern societies' (ECtHR, Demir and Baykara v. Turkey, para. 86).

European states' consensus constrains the court's evolutive interpretation of the ECHR and guides it. According to the ECtHR, the reference to consensus and the evolution of state practice actually amounts to a duty, and not just a possibility (see ECtHR, Sitaropoulos and Giakoumopoulos v. Greece, para. 66; ECtHR, Demir and Baykara v. Turkey, para. 85: 'can and must'). More specifically, the 'European consensus' so defined has been used to establish the degree or intensity of the margin of appreciation of states when specifying and restricting international human rights' duties (see, for example, Mowbray 2014; Spano 2014; Spielmann 2014; Dzehtsiarou 2015).

Regrettably, the 'European consensus' is not the sole criterion or test at play in the ECtHR's reasoning pertaining to the margin of appreciation, however, and its application remains largely unpredictable as a result (see, for example, Mowbray 2014; Spano 2014; Spielmann 2014; Dzehtsiarou 2015). Nevertheless, there are ways for the European consensus to be streamlined, and then generalized into other regional, but also universal human rights regimes (Besson 2017b).

Thus, the 'transnational human rights consensus' could work as the effectivity test for human rights' subsidiarity qua complementarity (see, for a full argument, Besson 2016b). Referring to the transnational consensus of democratic states as the minimal effective standard of human rights protection is the way to secure the democratic legitimacy of international human rights institutions' or courts' review without, however, turning international human rights case-law into an incoherent and hence non-egalitarian patchwork of individual domestic albeit democratic specifications (contra: Gerards 2014; Letsas 2017). Of course, the existence or absence of a transnational human rights consensus should only protect states' margin of appreciation within the egalitarian limits of subsidiarity, that is, provided non-discrimination rights and the fundamental core of human rights are not at stake. Conversely, and for the same democratic reasons, setting aside the priority of domestic authorities, and especially reducing their margin of appreciation, in cases that pertain to political rights that are therefore closely related to democracy, requires a strong degree of transnational consensus or, depending on the circumstances, may not even be justified in certain rare cases (see, for example, ECtHR, Sitaropoulos and Giakoumopoulos v. Greece, paras 63-5; see also Besson and Graf-Brugère 2014, pp. 953-4).

At this point, we may object that not all states are democratic, and that this jeopardizes the democratic argument for a democratic transnational consensus in human rights law (for a full discussion, see Besson 2018). This is a false problem, first, because all states parties to international human rights treaties have to be democratic as much as they have to respect human rights. Thus, their consensus has to be incrementally democratic, just as they incrementally have to protect human rights. Secondly, more specifically, when states have not ensured sufficient democratic deliberation in a given human rights case, their margin of appreciation should be limited or non-existent because the condition for the latter, that is domestic reason-giving, is not fulfilled (see Føllesdal 2017). As I explained before, in the absence of the latter, states should not be allowed to contribute further to the transnational development of the international human rights standard (Besson 2018). 


\section{CONCLUSIONS}

While constitutional law scholars have done some of the mapping of the transnational practice of human rights, and especially of comparisons in domestic (constitutional) and international human rights law, this is not yet true of their theoretical underpinnings. Aiming at filling this gap, and after some clarifications of the concept of transnationality in law in general and in human rights law in particular, the chapter started by justifying the transnationality of human rights law on democratic and epistemic grounds, before drawing implications for its determination methods whose practice remains largely irregular and in need of justification, that is, human rights comparison and the transnational human rights consensus it thereby identifies.

From a political perspective, the proposed transnational reading of human rights law has important implications for the way we should deal with the growing resistance against international human rights law and courts in democratic states. Those courts cannot and should not be identified with other international courts that enforce international law top-down and claim ultimate interpretative authority over domestic courts. As a result, domestic judges, and institutions more generally, should not fear to engage with international human rights law and courts for it is the only way international human rights law can develop and be interpreted transnationally and hence democratically. When they deliberate with one another over international human rights law, domestic institutions act neither as international law's agents or trustees nor as self-interested actors, contrary to what some scholars have argued, but as primary interpreters of our transnational constitutional values of democracy and human rights.

\section{REFERENCES}

Arendt, H. (1951), The Origins of Totalitariamism, London: Penguin, pp. 147-82.

Arjona, C., J. Anderson, F. Meier and S. Robart (2015), "What law for transnational legal education? A cooperative view of an introductory course to transnational law and governance', Transnational Legal Theory, 6 (2), 253-86.

Benhabib, S. (2011), Dignity in Adversity - Human Rights in Troubled Times, Malden, MA: Polity Press

Benvenisti, E. (1999), 'Margin of appreciation, consensus, and universal standards', NYU Journal of International Law a

Besson, S. (2009a), 'Whose constitution(s)? International law, constitutionalism and democracy', in J.L. Dunoff and J.P. Trachtman (eds), Ruling the World? Constitutionalism, International Law and Global Governance, Cambridge. Cans

after Kadi', European Constitutional Law Review, 5 (2), 237-64. .

Global Politics, 4 (1), 19-50. Pluralist Structure of Postnational Law', European Constitutional Law Review, 8 (2), 354-61.

esson, S. (2012b), 'The egalitarian dimension of human rights', Archiv fir Sozial- und Rechtsphilosophie Beiheft, 136, 19-52.

Besson, S. (2013a), 'Justifications', in D. Moeckli, S. Shah and S. Sivakumaran (eds), International Human Rights $L a w$, 2nd edn, Oxford: Oxford University Press, pp. 34-52.

Besson, S. (2013b), 'The allocation of anti-poverty rights duties - our rights, but whose duties?', in K.N. Schefer (ed.), Poverty and the International Economic Legal System - Duties to the World's Poor, Cambridge:

Cambridge University Press, pp. 408-31.
Besson, S. (2013c), 'The legitimate authority of international human rights', in A. Føllesdal, J.K. Schaffer and G. UIfstein (eds), The Legitimacy of International Human Rights Regimes: Legal, Political and Philosophical Perspectives, Cambridge: Cambridge University Press, pp. 32-83.
Besson, S. (2014), 'European human rights pluralism: notion and justification', in M. Maduro, K. Tuori and S. Sankari (eds), Transnational Law - Rethinking European Law and Legal Thinking, Cambridge: Cambridge University Press, pp. $170-205$

Besson, S. (2015a), 'Human rights and constitutional law: patterns of mutual validation and legitimation', in R Cruft, S.M. Liao and M. Renzo (eds), Philosophical Foundations of Human Rights, Oxford: Oxford University Press, 279-99.

Besson, S. (2015b), 'The bearers of human rights duties and responsibilities for human rights - a quiet (r)evolution', Social Philosophy \& Policy, 32 (1), 244-68.

Besson, S. (2015c), "International law's relative authority", a review of Nicole Roughan's Authorities: Conflicts. Cooperation and Transnational Legal Theory', Jurisprudence, 6 (1), 169-76.

Besson, S. (2016a), 'Legal human rights theory', in K. Brownlee, K. Lippert-Ramussen and D. Coady (eds), Blackwell Companion to Applied Philosophy, London: Blackwell Wiley, pp. 328-41.

Besson, S. (2016b), 'Subsidiarity in international human rights law - what is subsidiary about human rights?', American Journal of Jurisprudence, 61 (1), 69-107.

Besson, S. (2017a), 'The sources of international human rights law', in S. Besson and J. d'Aspremont (eds), Oxford Handbook on the Sources of International Law, Oxford: Oxford University Press, forthcoming.

esson, S. (2017b), 'The influence of the UN covenants on states parties across regions - some lessons for the role of comparative law and regions in international human rights law', in D. Moeckli and $\mathrm{H}$. Keller (eds), The UN Human Rights Covenants at 50, Oxford: Oxford University Press, forthcoming

(tilites Gaw, Oxford: Oxford

Besson, S. (2018), 'Comparative human rights law: human rights as a comparative project', in M. Reimann and

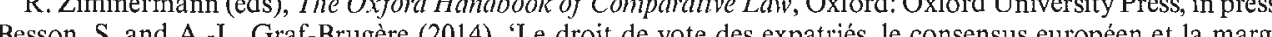
d'app. and A.-L. Graf-Brugere (2014), 'Le droit de vote des expatriés, le consensus européen et la marge d'appréciation des Etats - Un commentaire de
trimestrielle des droits de l'lomme, 100, $937-58$.

Brems, E. (1996) 'The margin of appreciation doctrine in the case-law of the European Court of Human Rights', Zeitscllrift für aluslïndisches öffentliches Recht und Volkerrecht, 56, 240-314.

Brems, E. (2014), 'Should pluriform human rights become one? Exploring the benefits of human rights integration $/$ Intégrer le droit des droits de l'homme: une exploration', European Journal of Human Rights I Journa européen des droits de l'honme, (4), 447-70.

Buchanan, A. (2004), Justice, Legitimacy, and Self-Determination: Moral Foundations for International Law, Oxford: Oxford University Press.

Buchanan, A. (2008), 'Human rights and the legitimacy of the international order', Legal Theory, 14 (1), 39-70. Buchanan, A. (2010a), 'Social moral epistemology and the tasks of ethics', in N.A. Davis, R. Keshen and J McMahan (eds), Ethics and Humanity - Themes from the Philosophy of Jonathan Glover, Oxford: Oxford University Press, pp. 105-25.

Buchanan, A. (2010b), 'The egalitarianism of human rights', Ethics, 120 (4), 679-710

Buchanan, A. (2011), 'Reciprocal legitimation: reframing the problem of international legitimacy', Politics Philosophy \& Economics, 10 (1), 5-19.

Buchanan, A. (2013), 'Moral progress and human rights', in C. Holder and D. Reidy (eds), Human Rights - The Hard Questions, Cambridge: Cambridge University Press, pp. 399-417.

uchanan, A. (2017), 'The reflexive social moral epistemology of human rights', in M. Fricker (ed.), Epistemic Buchanan, A and R. Powell (2008) "Constitutional dem

( col

rights, democracy and sovereignty in the age of globalization', Political Theory, 36 (4), 578-606.

Dzehtsiarou, K. (2015), European Consensus and the Legitimacy of the European Court of Human Rights Canbridge: Cambridge University Press.

Engle Merry, S. (1988), 'Legal pluralism', Law and Society Review, 22 (5), 869-96.
Engle Merry, S. (2015), 'Firming up soft law: the impact of indicators on transnational human rights lega orders', in T.C. Halliday and G. Shaffer (eds), Transnational Legal Orders, Cambridge: Cambridge University Press, pp. 374-99.

Follesdal, A. (2017), 'Appreciating the margin of appreciation', in A. Etinson (ed.), Human Rights: Moral or Political?, Oxford: Oxford University Press, forthcoming

Gardbaum, S. (2008), 'Human rights as international constitutional rights', European Journal of International $\operatorname{Law}, 19$ (4), 749-68.

Gerards, J. (2014), 'The European Court of Human Rights and the national courts: giving shape to the notion of "shared responsibility", in J. Gerards and J. Fleuren (eds), Inplementation of the European Convention on 
Human Rights and of the Judgments of the ECtHR in National Case-Law - A Conparative Analysis, Antwerp: Intersentia, pp. 13-94. Gibney, M. and W. Vandenhole (eds) (2014), Litigating Transnational Human Rights Obligations - Alternative
Judgments, London: Routledge.

Gibney, M., K. Tomasevski and J. Vedsted.Hansen (1999), 'Transnational state responsibility for violations of human rights', Harvard Human Rights Journal, 12, 267-95.

Habermas, J. (2011), Zur Verfassung Europas - Ein Essay, Berlin: Suhrkamp.

Halliday, T.C. and G. Shaffer (eds) (2015), Transnational Legal Orders, Cambridge: Cambridge University Press Halmai, G. (2012), The use of foreign law in constitutional interpretation', in M. Rosenfeld and A. Sajo (eds), The Oxford Handbook of Comparative Consthntional Law, Oxford: Oxford University Press, pp. 1328-48. Hessler, K. (2005), 'Resolving interpretive conflicts in international human rights law', Journal of Political Plilosophy, 13 (1), 29-52.

Hirschl, R. (2014), Comparative Matters: The Renaissance of Comparative Constitutional Law, Oxford: Oxford University Press.

Jackson, V.C. and M. Tushnet (2014), Comparative Constitutional Law, 3rd edn, St Paul, MN: Foundation Press Jessup, P.C. (1956), Transnational Law, New Haven, CT: Yale University Press.

Keck, M.E. and K. Sikkink (1998), Activists Beyond Borders, Ithaca, NY: Cornell University Pres

Klabbers, J., A. Peters and G. Ulfstein (2009), The Constitutionalization of International Law, Oxford: Oxford University Press

Klug, H. (2005), 'Transnational human rights: exploring the persistence and globalization of human rights',

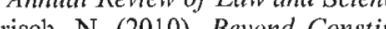

Constitutionalism: The Pluralist Structure of Postmational Law, Oxford: Oxford University Press.

Kumm, M. (2009), 'The cosmopolitan turn in constitutionalism: on the relationship between constitutionalism in and beyond the state', in J.L. Dunoff and J.P. Trachtman (eds), Ruling the World? Constitutionalism, International Law and Global Governance, Cambridge: Cambridge University Press, pp. 258-325.

Kumm, M. (2012), 'The moral point of constitutional pluralism: defining the domain of legitimate institutional civil disobedience and conscientious objection', in J. Dickson and P. Eleftheriadis (eds), Philosophich Foundations of European Union Law, Oxford: Oxford University Press, pp. 216 46.

Letsas, G. (2010), 'Strasbourg's interpretative ethic: lessons for the international lawyer', European Journal of International Law, 21 (3), 509-41.

Letsas, G. (2017), 'The margin of appreciation revisited: a response to Fellesdal', in A. Etinson (ed.), Humcm Rights: Moral or Political?, Oxford: Oxford University Press, forthcoming.

Marti, J.L. (2006), 'The epistemic conception of deliberative democracy defended: reasons, rightness and equal political autonomy', in S. Besson and J.L. Martí (eds), Deliberative Democrac' and Its Discontents, Aldershot: Ashgate, pp. 27-56.

McCrudden, C. (2000), 'Common law of human rights? Transnational judicial conversations on constitutional rights', Oxford Journal of Legal Studies, 20 (4), 499-532.

McCrudden, C. (2007), 'Judicial comparativism and human rights', in E. Orücü and D. Nelken (eds), Comparative Law: A Handbook, Oxford: Hart, pp. 371-98

McCrudden, C. (2013), 'Using comparative reasoning in human rights adjudication: the Court of Justice of the European Union and the European Court of Human Rights compared', Cambridge Yearbook of European

McCrudden, C. (2014), 'The pluralism of human rights adjudication', in L. Lazarus, C. McCrudden and Pights: Comparative Judicial Engagement, Oxford: Hart, $\mathrm{pp}$. 3-27.

C. (2015), "Why do national court judges refer to human rights treaties? A comparative international law analysis of CEDAW', American Journal of International Law, 17 (3), 534-50.

Crudden, C. (2017), 'Comparative international law and human rights: a value-added approach', in A. Roberts, P.B. Stephan, P.-H. Verdier and M. Versteeg (eds), Comparative International Law, Oxford: Oxford University Press, forthcoming.

Michaels, R. (2014), 'What is non-state law? A primer', in M.A. Helfand (ed.), Negotiating State and Non-State Law - the Challenge of Global and Local Legal Pluralism, Cambridge: Cambridge University Press, pp. 41-58. Mowbray, A. (2014), 'Subsidiarity and the European Convention on Human Rights', Humon Rights La" Review, 15 (2), 313-41.

Muir Watt, H. (2011), 'Private international law beyond the schism', Transnational Legal Theory, 2 (3), 347-427. Neuman, G.L. (2003), 'Human rights and constitutional rights: harmony and dissonance', Stanford Lav Review, $\mathbf{5 5}(5), 1863-900$.

Neuman, G.L. (2008), 'Import, export, and regional consent in the Inter-American Court of Human Rights', European Journal of International Law, 19 (1), 101-23.

Pavlakos, G. (2015), 'Transnational legal responsibility: some preliminaries', in W. Vandenhole (ed.), Challenging
Tervitoriality in Human Rights Law - Building Blocks for a Plural and Diverse Duty-Bearer Regime, London: Routledge, pp. 136-57.

Scott, C. (2009), 'Transnational law as proto-concept: three conceptions', German Law Journal, 10 (7), 859-76. (October), 231-53.

Skogly, S.I. and M. Gibney (2002), 'Transnational human rights obligations', Human Rights Quarterly, 24 (3), 781-98.

Spano, R. (2014), 'Universality or diversity of human rights? Strasbourg in the age of subsidiarity', Human Rights Law Review, 14 (3), 487-502.

Spielmann, D. (2014), 'Whither the margin of appreciation?', Current Legal Problems, 67 (1), 49-65.

Teubner, G. (1996), 'Global Bukowina: legal pluralism in the world society', in G. Teuber (ed.), Global Law without a State, London: Dartmouth, pp. 3-28

Twining, W. (2009), General Jurisprudence: Understanding Law from a Global Perspective, Cambridge: Cambridge University Press.

Vandenhole, W. (2012), 'Emerging normative frameworks on transnational human rights obligations', EUI Working Papers No. RSCAS 2012/17, European University Institute, Florence.

Vandenhole, W. (2015), 'Obligations and responsibility in a plural and diverse duty-bearer human rights regine', in W. Vandenhole (ed.), Challenging Territoriality in Human Rights Law: Building Blocks for a Plural and Diverse Duty-Bearer Regime, London: Routledge, pp. 115-35.

Waldron, J. (2005), 'Foreign law and the modern ius gentium', Harvard Law Review, 119 (1), 129-47.

Thon, J. (201), Righ and to teds),

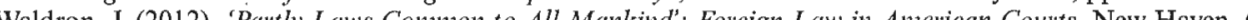
and London: Yale University Press.

Wiener, A. A. Lang, J. Tully, M. P. Maduro and M. Kumm (2012), 'Global constitutionalism: human rights, democracy and the rule of law', Global Constitutionalism 1 (1), 15.

Wildhaber, L., A. Hjartarson and S. Donnelly (2013), 'No consensus on consensus', Human Rights Lai' Journal, 33 (7) 248-63.

Ziemele, I. (2012), 'Customary international law in the case law of the European Court of Human Rights', in L. Lijnzaad and Council of Europe (eds), The Judge and International Custom, Strasbourg: Editions du Conseil de l'Europe, pp. 75-83.

Zoethout, C.M. (2015), 'The European Court of Human Rights and transnational judicial dialogue - references to foreign law and the quest for justification', Vienna Journal on International Constitutional Law / ICL Journal, 9 (3), $398-416$.

Zumbansen, P. (2005), 'Beyond territoriality: the case of transnational human rights litigation', Research Paper No. 258, Osgoode Hall Law School, York University, accessed 2 May 2017 at http://digitalcommons, osgoode. yorku.ca/all_papers/258.

Zumbansen, P. (2010), 'Transnational legal pluralism', Transnational Legal Theory, 1 (2), 141-89. Zumbansen, P. (2013), 'Why global law is transnational', Transnational Legal Theory, 4 (4), 463-75.

Zumbansen, P. (2015), 'Theorizing as activity: transnational legal theory in context', in U. Baxi, C. McCrudden and A. Paliwala (eds), Law's Ethical, Global and Theoretical Contexts - Essays in Honotur of William Twining, 